\author{
D.A. Kazimova*, A. Tussipkhan, G. Adilkhan, \\ A. Suinkhan, E. Tileukhabyl \\ Karagandy university of the name of academician E.A.Buketov, Kazakhstan \\ (*Corresponding author's e-mail:dinkaz73@mail.ru)
}

\title{
Implementation of pedagogical solutions to increase the efficiency of the digitalization of learning at the university
}

\begin{abstract}
The article discusses the implementation of digital technologies in the higher education system, which opens up new opportunities for the design of new pedagogical solutions. The authors highlight the ways to create a digital educational space and content application through digital technologies. The main directions of implementation of pedagogical solutions to improve the results of the teaching and learning process in the context of digitalization of education are described. The main areas of application of ICT tools in the educational process of the University for improving the content of teacher education are considered, formation of a high level of information culture. The means of using interactive innovative technologies, automated systems are analyzed, allowing to equip with new information arrays of resource support of the university, for the competent use by teachers of the potential of modern information technologies for solving practice-oriented tasks of professional activity. All of these diverse methods and approaches, selected by the authors contribute to the development of students ' creative abilities, mastering new technologies.
\end{abstract}

Keywords: digital technologies, pedagogical solutions, digital educational space, digitalization of education, innovative technologies, Information Technology, digital pedagogy, information resource.

\section{Introduction}

The education system of the Republic of Kazakhstan is focused on entering the world educational environment, so the quality of education is considered in the context of compliance of the level of educational services received with international standards and norms. At the same time, the priority is to achieve a quality of training that will enable them to compete in the international labor market. The quality education is constitutional right of every citizen of the Republic of Kazakhstan.

Currently, the functions of education, school and the professional status of a teacher are complicated by the changes taking place in society. The new conditions associated with changes in education and in school put forward new requirements.

Everything is integrated in the world: economics, science, culture, approaches and concepts. In this regard, there is an increasing need for the development of the individual personality, its qualitative changes, responsibility and readiness for self-realization, the ability to socialize and adapt to rapidly changing world, the ability to create will be required, the demand for knowledge will increase.

In the context of modern education, the most topical is the activity character and is the key to the increasing efficiency of education, since «abilities are manifested and developed in activity».

The transition to digitalization requires the education system to solve a fundamentally new problem of training specialists who are adapted to the rapidly changing realities of the environment, who are able not only to perceive, store and reproduce information, but also to produce new, manage and efficiently process big data. The change in training requirements for specialists is dictated by the emergence of new types of theoretical and practical problems, which are distinguished by systemic and interdisciplinary nature, nonstandard, global possible consequences [1].

Such tasks do not have simple and unambiguous solutions, which requires a significant change in the nature of all professional activities of specialists and makes it necessary to train specialists of a new type who can see the situation as a whole, to approach the search for a solution creatively, able to predict its result, aware of their personal contribution and responsibility.

The wide use of information technologies is primarily associated with the dynamic trend in the development of innovations in the field of education, which is gaining more and more turnover from year to year. Today, the Internet, cloud computing, mobile and multimedia technologies, social technologies, big data, intelligent systems and much more have become a mandatory attribute of countries with smart economies. 
A modern teacher should competently use the potential of modern information technologies to solve practical-oriented tasks of professional activity. One of the most important elements of the teacher's professional activity is his information resource.

The activity of the teacher has successive and perspective character, based on the experience of the past, designs the development of the person for the future. The teacher always needs to professionally master the experience of the past, especially well navigate in modern life and predict the contours of the future, anticipate events that may be in upcoming life.

\section{Experimental}

A professional teacher not only teaches others, but also constantly learns, improving skills. If he does not enrich his knowledge, then the time will come when he will give nothing to others. Thus, continuing education is a characteristic feature of the teaching profession.

Implementation of comprehensive and qualitative training of the future teacher, corresponding to qualification categories of teacher-moderator, teacher-expert, teacher-researcher, teacher-master, who is able to effectively use modern digital technologies in educational practice, conduct scientific and pedagogical research using ICT, effectively manage the educational process based on the use of digital tools.

The modern stage of the development of society is characterized by penetration into all spheres of activity of information and communication technologies, including the system of education. This trend is typical for educational institutions of any level of education: schools, colleges, universities, advanced training courses, etc.

As an example, we consider the situation in higher education. Firstly, in higher educational institutions, information and communication technologies (ICT) become the content of education - the work curriculum of any university contains IT disciplines that form general cultural competencies among students, which involve the possession of basic methods and technologies for managing information, as well as the ability to use software to store, present, process information and transfer it with the help of communication technologies [2].

\section{Results and Discussion}

At E.A. Buketov Karaganda University in the content of the preparation of bachelors of education according to the educational program 6B01505 - Computer science, 6B01506-Computer science, ICT and robotics in the module «Educational technologies» contains disciplines, forming competencies in the field of teaching methods in educational sphere, such as «Educational robotics,» «Robotic programming systems,» «Mobile robotics,» «Methodology for teaching computer science,» «Fundamentals of teaching computer science within the framework of updated content of secondary education,» «Fundamentals of CLILtechnology,» «Innovative technologies for organizing the school educational process,» «Digital educational resources,» «Technology of criterion assessment,» «IT startups», «Information and communication technologies in education». This module includes elective courses aimed at teaching students on the use of CLIL, digital educational resources.

The innovative educational program «8D01100103 — Digital pedagogy» at the level of doctoral study has been opened at E.A. Buketov Karaganda University.

The purpose of the educational program is to train competitive specialists who are proficient in digital technologies and modern research methods in the field of digital pedagogy [3].

Content of professional activity:

- provides teaching of information and pedagogical cycle disciplines;

- creates universal values and the desire for professional and scientific growth among the participants of the educational process;

- develops and implements methodological support in the educational process, taking into account the achievements of digital pedagogy, psychology, ICT and computer science;

- organizes and conducts research on topical issues of ICT and psychological and pedagogical science;

- interacts with all interested professional communities in order to promote and implement innovations in professional activities;

- carries out management activities taking into account the development of education and science. 
Functions of professional activity of the educational program are:

- training transmits educational information, teaches to independently obtain knowledge, designs training sessions taking into account the linguistic needs and demands of students, uses new technologies for teaching digital pedagogy, including digital technologies and ICTs, etc.;

- educating introduces students to the system of social values, observance of pedagogical tact, rules of pedagogical ethics, shows respect for the personality of students, builds the educational process taking into account the national priorities of Kazakhstan, etc.;

- methodological provides methodological support for the information and educational environment, determines the content of the course (module); methods for developing and implementing educational programs of higher education specialties, including taking into account the training of multilingual personnel; designs educational programs of University specialties; manages scientific and methodological support of educational programs of University specialties; implements author's programs; develops educational materials, digital educational resources, etc.;

- research identifies problems, conducts psychological and pedagogical research in the field of digital pedagogy, implements research results in professional activities; directs research of students, undergraduates, doctoral students;

- social and communicative interacts with the professional community and with all interested sides, initiates innovative ideas that unite educational stakeholders, etc.;

- management manages processes in the context of General trends in the development of education and science, the General strategic direction of the development of the organization of education.

Secondly, ICTs are becoming learning tools. It is already difficult to imagine a modern educational process without using e-mail, software for creating presentations, videos and audio materials from the Internet. Increasingly, universities are using LMS (Learning Management System) - learning management systems, the interface of which allows you to place educational materials on the subject, homework, control activities, organize access to them and feedback from the teacher. The explosion of interest in mass open online courses (MOOC) based on such platforms as Coursera, Udacity, edX, FutureLearn, Iversity, Udemy led to the creation of a national platform «Open education», where Russian universities place online courses [4].

Smart education integrates new concepts of digital pedagogy:

- open educational resources (opr)

- mass open online courses (mooc)

- learning management system (lms)

- electronic textbooks (smartbook/e-book)

- electronic libraries (e- library)

- open licenses (e.g. mop licenses)

- mobile training

- cloud education and internet services (web 3.0)

- digital video communications

- global media

- automated educational management systems (e.g. smart systems).

In this regard, there is a high demand for mass open online courses on new ICT competencies of teachers. These courses are a new step towards the deployment of digital pedagogy, since this requires a rethinking of the ICT competence of teachers - from user technological to project methodological. A digital school is undoubtedly a school working in the digital pedagogy system.

Thirdly, there are webinars - online analogues of classical organizational forms of training - lectures and seminars. Thanks to all the above technologies, new opportunities have been created to implement training methods. Objectively, the current situation with the widespread use of ICTs required a new program from the state.

At Buketov Karaganda University, teachers introduce innovative approaches in the training of teachers with an emphasis on improving the content of teacher education, creating a high level of information culture, and implementing training using distance technologies. Teaching staff of the Department during training sessions necessarily use a variety of methods for developing electronic educational materials: multimedia technologies, SMARTlearning technologies, an electronic textbook of the Cisco network Academy, case study technology, the use of video materials in the study of disciplines, creating video lessons in the CamStudio program, creating testing tasks in the iSpringQuizMaker program; preparing multimedia 
materials by means of: iSping, Prezzy, Powtoon, etc. The project-organized approach is implemented in the implementation of independent work by students of educational programs, in the technology of developing individual and group tasks for students.

Student-centered training requires continuous professional development of teachers, including the ability to plan educational work on the subject, choose teaching methods and computer applications, taking into account the features of these technologies and the profile of the specialty, and the use of appropriate software. Teachers of the Department introduce innovative approaches in the preparation of bachelors of education with an emphasis on improving the content of teacher education, the formation of a high level of information culture.

The faculty of mathematics and information technology also hosts events in certain scientific areas: online seminars, master classes, open lectures, student scientific conferences. To increase knowledge and develop creative abilities, students are engaged in clubs. The purpose of the «Programming» group is to develop students' algorithmic thinking. The purpose of the «Robotics» club is to master programming in the LEGO Robolab computer simulation environment and prepare for competitions in educational robotics. All these various methods and approaches contribute to the development of students' creative abilities.

The University has an electronic database of students by type of academic programs and level of education. The Registrar's office can use the Credit technology module in electronic University system (e.ksu.kz) of the Karaganda University to work with the electronic database of students. The policy and marketing strategy of the University aimed at the attraction of the necessary number of students, as well as requirements for admission and special conditions for admission to academic programs are posted on the website of Karaganda University [5].

The Registrar's office and students of the program have the opportunity to track academic achievements, final annual attestation results, transcripts by means of the «Electronic University» system.

The University operates a computer network with Internet access, covering all departments of the University, as well as computer classes and library halls. The Internet connection bandwidth is $500 \mathrm{Mbit} / \mathrm{s}$. Wi-Fi access points are available in all buildings of the University. The University has a unified corporate information system for teachers and students «Electronic University» (www.e.ksu.kz), which includes such modules as «Curriculum», «Credit technology», «Bank of professional achievements of teaching staff», «student's personal account», «teacher's personal account», etc.

In Electronic University, the information and resource support subsystem is a single system of information and library services. This provides support for students and teachers, academic accessibility of information resources, library collections. The electronic catalog of library resources allows you to search for the necessary literature and provides access to electronic versions of individual textbooks and teaching materials.

The library of E.A. Buketov Karaganda University provides students and teachers with free access to printed and electronic resources: educational, technical, reference specialized literature, periodicalsprofessionally oriented journals; electronic lectures of teaching staff, multimedia educational presentations, digitized educational publications and scientific articles.

Thanks to the development of the material and technical subsystem, students and teachers have free access to the Internet, which allows teachers to actively use Internet resources (Web sites, educational portals) in their educational activities, and students - to carry out independent work. The use of Web resources and technologies plays an important role in the training of modern students.

The subsystem of information and resource support of E.A. Buketov University is closely connected with the subsystem of methodological support.

The subsystem includes methodological support of educational-methodical complexes of subjects (typical and working curriculm, model programs), educational-methodical complexes of disciplines, educational and training manuals, e-lectures, multimedia learning presentations, electronic textbooks and training programs, methodical recommendations to performance of practical and laboratory works, lists of recommended literature and Internet sources and other methodical materials intended for different participants in the educational process. Teachers place prepared electronic educational resources on the website of the University library.

This subsystem operates on the basis of the network corporate information system of teachers and students «electronic University of KU» (www.e.ksu.kz), which includes a number of modules. For example, the module «Curriculum» allows you to create working curricula of educational programs, assign disciplines to departments. 
The module «Credit technology» allows you to create individual plans for students, keep records of academic performance, and make a transcript of the student.

The module «calculation and distribution of teaching load» allows you to calculate the annual load of teachers of all departments on the basis of formed working curriculum, taking into account the approved standards for calculating the academic load.

The module «scheduling classes» allows to create a schedule of classes taking into account the employment of the classroom fund, the contingent of students, the formed pedagogical load of teachers. Through the «Schedule» module, students and teachers track the current schedule, as well as the schedule of boundary and final controls.

The «student's personal account» module provides the student with authorized access to personal results of academic achievements throughout the entire period of study. The module «Student Department» allows you to create a database of students in the context of personal data, educational programs, forms and languages of study.

The «teacher's personal account» module allows the teacher to use several sections: «Individual work plan of the teacher», "Electronic log of pedagogical load fulfillment», section «Electronic log of class attendance and students' tasks» - allows you to keep records of students 'attendance and record current academic performances, section «test loading» — is intended for uploading tests personally by the teacher to the University database for conducting boundary and final controls.

The module «Bank of professional achievements of teaching staff» allows you to form academic ratings of teachers based on the results of educational, methodological, and research work.

The University has an official website (www.ksu.kz) in Kazakh, Russian, and English. The site presents Buketov University on Internet, contributes to the formation of the University's image, provides an information environment for applicants, students, employers, graduates, and employees of the University, and ensures openness and accessibility of information. The website provides access to educational and scientific resources, as well as access to scientific electronic databases as part of a subscription, as well as open access (Section «Scientific library»): Academic on-line journal of the American Association for the advancement of science (AAAS) «Science», «Thomson Reuters», Elsevier's Science Direct, Scopus reference and search database, Springer.

Buketov Karaganda University uses various methods for posting information about the educational program: through the University's website (the «Applicant» section), information stands, booklets, mass media (Newspapers, television), and social networks.

Social networks have webpages of the University and faculty on various issues, for example, Instagram has a page for applicants and first-year students, G-Global has created a communication platform for publishing articles and notes of scientific content for teachers, students and undergraduates [6].

Digital school is an objective transformation of the General education system in the conditions of digitalization of the Republic of Kazakhstan. We are on the threshold of change and are participating in the formation of a new education system in the world - digital education.

Digital learning provides many new opportunities in the development of new teaching methods and technologies. Their diversity makes it possible to meet the individual needs of students and implement digital pedagogy in practice.

We should also mention new methods - the use of interactive technologies, computer and virtual laboratories, search engines, databases that allow you to equip the search and research work of students with new information arrays, including the collection, analysis and processing of selected or independently prepared information.

\section{Conclusions}

Thus, working on creating an information resource, teachers constantly improve their digital literacy, master new technologies and master new services. And in order to constantly improve in the sphere of digital information literacy, it is necessary to study and take distance courses on educational resources.

\section{References}

1 Казимова Д.А. Подготовка ИТ-специалистов в условиях цифровизации: моногр. / Д.А. Казимова. — Караганда: Издво КарГУ, 2018. - 140 с. 
2 Горбунова Н.А. Модульный принцип построения образовательной программы профессиональной подготовки учителей информатики в условиях модернизации современного образования / Н.А. Горбунова // Вестн. Караганд. ун-та. Сер. Педагогика. — 2019. — № 4(96). — С. 56-64.

3 Профессиональные стандарты [Электронный ресурс]. - Режим доступа: http://atameken.kz/ 542-profstandart/

4 Дендев Б. Коммуникационные технологии в образовании: моногр. / Б.Дендев. - М.: Ин-т ЮНЕСКО по информ. техн. в обр., 2013. - 321 с.

5 Спирина Е.А. Развитие информационной образовательной среды университета как условие совершенствования учебно-методической работы / Е.А. Спирина, Д.А. Казимова, С.А. Муликова // Вестн. Новосиб. гос. пед. ун-та. — 2017. № 4. - C. 26-39.

6 Kazimova D.A. Innovative approaches in training specialists in conditions of digitalization of education / D.A. Kazimova, B.Zh. Abdrasheva, M.T. Baimukanova, K.L. Polupan, N.A. Musatai // Bulletin of the Karaganda University. «Pedagogy» series. 2018. - T. 4. - P. 89-94.

\author{
Д.А. Казимова, А. Түсіпхан, Г. Әділхан, А. Сүйінхан, Е. Тилеухабыл
}

\title{
Жоғары оқу орындарында оқытуды цифрландыру процесінің тиімділігін арттыру мақсатында педагогикалық шешімдерді іске асыру
}

\begin{abstract}
Мақалада жаңа педагогикалық шешімдерді жобалауға жаңа мүмкіндіктер ашатын жоғары білім беру жүйесіне цифрлық технологияларды енгізу мәселелері қарастырылды. Авторлар сандық білім беру кеңістігін құру және сандық технологиялар арқылы мазмұнды қолдану жолдарын анықтайды. Білім беруді цифрландыру жағдайында оқыту және оқыту процесінің нәтижелерін жақсарту мақсатында педагогикалық шешімдерді іске асырудың негізгі бағыттары сипатталған. Педагогикалық білім беру мазмұнын жетілдіру, ақпараттық мәдениеттің жоғары деңгейін қалыптастыру үшін университеттің білім беру процесінде АКТ құралдарын қолданудың негізгі бағыттары қарастырылды. Интерактивті инновациялық технологияларды, университеттің ресурстық қамтамасыз етуінің жаңа ақпараттық массивтерімен жабдықтауға мүмкіндік беретін автоматтандырылған жүйелерді пайдалану құралдары, педагогтердің кәсіби қызметінің практикалық-бағытталған міндеттерін шешу үшін заманауи ақпараттық технологиялардың әлеуетін сауатты пайдалануы үшін талданды. Авторлар бөлген осы әр түрлі әдістер мен тәсілдер студенттердің шығармашылық қабілеттерін дамытуға, жаңа технологияларды игеруге ықпал етеді.
\end{abstract}

Кілт сөздер: цифрлық технологиялар, педагогикалық шешімдер, цифрлық білім беру кеңістігі, білім беруді цифрландыру, инновациялық технологиялар, ақпараттық технологиялар, цифрлық педагогика, ақпараттық ресурс.

\section{Д.А. Казимова, А. Түсіпхан, Г. Әділхан, А. Сүйінхан, Е. Тилеухабыл \\ Реализация педагогических решений в целях повышения эффективности процесса цифровизации обучения в вузе}

\begin{abstract}
В статье рассмотрены вопросы внедрения цифровых технологий в систему высшего образования, которые открывает новые возможности для проектирования новых педагогических решений. Авторами выделены пути создания цифрового образовательного пространства и применения контентов посредством цифровых технологий. Описаны основные направления реализации педагогических решений в целях улучшения результатов процесса преподавания и обучения в условиях цифровизации образования. Рассмотрены основные области использования средств ИКТ в образовательном процессе университета для совершенствования содержания педагогического образования, формирования высокого уровня информационной культуры. Проанализированы возможности интерактивных инновационных технологий, автоматизированных систем, позволяющих оснастить новыми информационными массивами ресурсного обеспечения университета, для грамотного использования педагогами потенциала современных информационных технологий для решения практикоориентированных задач профессиональной деятельности. Все эти разнообразные методы и подходы, выделенные авторами, способствуют развитию у обучающихся творческих способностей, овладению новыми технологиями.
\end{abstract}

Ключевые слова: цифровые технологии, педагогические решения, цифровое образовательное пространство, цифровизация образования, инновационные технологии, информационные технологии, цифровая педагогика, информационный ресурс. 


\section{References}

1 Kazimova, D.A. (2018). Podhotovka IT-spetsialistov v usloviiakh tsifrovizatsii [Training of it specialists in the conditions of digitalization]. Karaganda: Izdatelstvo Karahandinskoho hosudarsvennoho universiteta [in Russian].

2 Gorbunova, N.A. (2019). Modulnyi printsip postroeniia obrazovatelnoi prohrammy professionalnoi podhotovki uchitelei informatiki $\mathrm{v}$ usloviiakh modernizatsii sovremennoho obrazovaniia [Modular principle of building an educational program for professional training of computer science teachers in the context of modernizing modern education]. Vestnik Karahandinskoho universiteta. Seriia Pedahohika - Bulletin of the Karaganda University. Pedagogy series, 4(96), 56-64 [in Russian].

3 Professionalnye standarty [Professional standards]. (n.d.). atameken.kz. Retrieved from http://atameken.kz/ 542-profstandart/ [in Russian].

4 Badarch, Dendev. (2013). (Eds.). Informatsionnye i kommunikatsionnye tekhnolohii v obrazovanii [Information and communication technologies in education]. Moscow: Institut YUNESKO po informatsionnym tekhnolohiiam v obrazovanii [in Russian].

5 Spirina, E.A., Kazimova, D.A., \& Mulikova, S.A. (2017). Razvitie informatsionnoi obrazovatelnoi sredy universiteta kak uslovie sovershenstvovaniia uchebno-metodicheskoi raboty [Development of the information educational environment of the University as a condition for improving educational and methodological work]. Vestnik Novosibirskoho hosudarstvennoho pedahohicheskoho universiteta - Bulletin of the Novosibirsk state pedagogical University, 4, 26-39 [in Russian].

6 Kazimova, D.A., Abdrasheva, B.Zh., Baimukanova, M.T., Rolupan, K.L., \& Musatai, N.A. (2018). Innovative approaches in training specialists in conditions of digitalization of education. Bulletin of the Karaganda University. Pedagogy series, 4, 92, 89-94. 